ENTREPRENEURSHIP AND SUSTAINABILITY ISSUES

ISSN 2345-0282 (online) http://jssidoi.org/jesi/

2020 Volume 7 Number 4 (June)

http://doi.org/10.9770/jesi.2020.7.4(7)

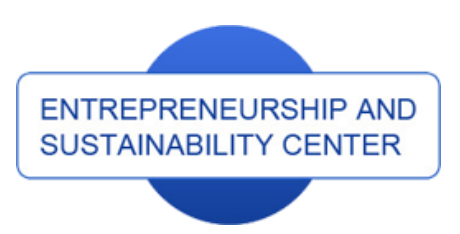

Publisher

http://jssidoi.org/esc/home

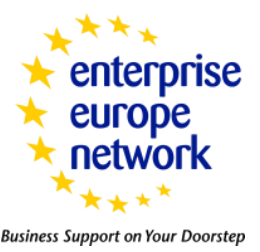

CASPA

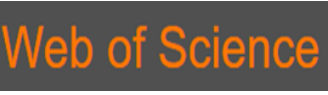

1) Clarivate

\title{
LINKS BETWEEN CORRUPTION AND QUALITY OF LIFE IN EUROPEAN UNION*
}

\author{
Rita Remeikienė ${ }^{1}$, Ligita Gasparėnienė ${ }^{2}$, Viktoras Chadyšas ${ }^{3}$, Evaldas Raistenskis ${ }^{4}$ \\ 1,2 Mykolas Romeris University, Faculty of Economics and Business, Ateities str. 20, Vilnius, Lithuania \\ ${ }^{3}$ Vilnius Gediminas Technical University, Faculty of Fundamental Sciences, Sauletekio av. 11, Vilnius, Lithuania \\ ${ }^{4}$ Vilnius University, Faculty of Law, Sauletekio av. 9, Vilnius, Lithuania
}

\begin{abstract}
E-mails: ${ }^{1}$ rita.remeikiene@mruni.eu (Corresponding author); ${ }^{2}$ ligitagaspareniene@mruni.eu ; ${ }^{3}$ viktoras.chadysas@vgtu.lt;
4 evaldas.raistenskis@cr.vu.lt
\end{abstract}

Received 15 November 2019; accepted 10 March 2020; published 30 June 2020

\begin{abstract}
Studies looking at the links between corruption and quality of life have begun to take place recently, as until now the quality of life has not traditionally been associated with political decisions. Corruption may be defined as the abuse of entrusted power for private gain, which in one way or another affects the quality of life and satisfaction of others. The aim is to bridge the gap between the nexus of corruption and the quality of life in the EU. EU countries were divided into groups of countries according to the year of accession and cover the years 2004-2017 period. The EU has been selected as a geographical region with the aim of uneven economic development of the countries and the lack of research in the region. The aim of the article is to determine the interdependencies between corruption and quality of life indicators in EU countries. Multivariate regression models revealed that the prevalence of corruption among individual groups of six countries had the highest impact on mortality rates, unambiguously showing how well countries are managing their health care systems, population density, birth rate and population aging, GDP per capita, economic situation, life expectancy, serving as an indicator of quality of life and the number of people with primary education. The results of empirical research allow to form insights that in order to reduce corruption it is necessary to focus on the following spheres reflecting the quality of life: education, health care system and general economic situation of the country. The article used the following methods: comparative and systematic literature analysis, multiple regression analysis.
\end{abstract}

Keywords: corruption; European Union; life quality; well-being

Reference to this paper should be made as follows: Remeikienė, R., Gasparėnienè, L., Chadyšas, V., Raistenskis, E. 2020. Links between corruption and quality of life in European Union. Entrepreneurship and Sustainability Issues, 7(4), 2664-2675. http://doi.org/10.9770/jesi.2020.7.4(7)

JEL Classifications: E26, D73

Additional disciplines: mathematics, law

\footnotetext{
* This research was supported by the project "Interdependence between illegal turnover in tobacco and corruption, money laundering and organised crime", which has received funding from Phillips Morris International Management SA, the number of Grant Agreement Number PRC-9.
} 


\section{ENTREPRENEURSHIP AND SUSTAINABILITY ISSUES}

ISSN 2345-0282 (online) http://jssidoi.org/jesi/

2020 Volume 7 Number 4 (June)

http://doi.org/10.9770/jesi.2020.7.4(7)

\section{Introduction}

The concept of quality of life is very broad and multifaceted, with no single definition due to its multidimensional nature. The concept of quality of life encompasses various aspects of human life (health, social well-being, psychology, standard of living). Quality of life becomes a key objective of national governance and strategic planning and an indicator of policy effectiveness. Corruption is one of the factors of the quality of life in the external environment. Studies and foreign experience show that countries with democratic traditions, human rights and freedoms are more open to high quality of life than countries with totalitarian regimes, unstable political situations, prosperous corruption and abuses of public service for private purposes. The less corruption at the state or local level, the more reason to implement the principles of efficiency and transparency in the redistribution of social funds, which positively influences the satisfaction of the population with government policies and at the same time reflects their attitudes and behaviors. According to Shumach (2018), low-income countries, countries with closed economies, low media freedom and relatively low levels of education are considered to be more prevalent in corruption. Corruption inhibits economic growth and affects business operations, employment and investment. Corruption also reduces the revenue from taxes and the effectiveness of various financial assistance programs. For the general public, high levels of corruption reduce confidence in the law, the legal system and consequently in the quality of life (health care, access to infrastructure, education). An analysis of the scientific literature (Wu, Zhu, 2016; Cárcaba, et al., 2017; Anderson, 2016) has revealed a lack of research revealing interdependencies between corruption and quality of life.

The main purpose of the article is to establish the interdependencies between corruption and quality of life indicators in EU countries. The following tasks are pursued: 1. To study the theoretical aspects of the correlation between quality of life and corruption. 2. Justify the appropriateness of the chosen methodology; 3. Empirically evaluate the interdependencies between corruption and quality of life in EU countries.

Research methods: comparative and systematic literature analysis, multiple regression analysis.

\section{Literature review: existing links between corruption and quality of life}

Famous ancient Greek philosophers like Aristotle and Plato wrote in their works about human happiness and the fullness of life. These philosophers sought guidance on the meaning of life, believing that they could help to attain a higher level of existence. A.C. Pigou was the first to use the concept of quality of life in his book on economics and well-being, but this concept was ignored and ignored until about the end of World War II. According to Rakauskienė \& Servetkienè (2011), the notion of quality of life did not arouse greater interest in the scientific community and was commonly used as a concept requiring no explanation. According to Gruževskis \& Orlova (2012), the concept of quality of life circa 1960. was established as a term of public political discourse and was used in political rhetoric to say that it matters not "how much, but how well." More broadly speaking, socioeconomic research as a component of quality of life and individual development in the world began only in the 20th century (Schuessler, Fisher, 1985). Since then, various scientific disciplines have begun to analyze the quality of life and its determinants. Various models of quality of life and their measurement tools have been developed since the middle of the last century (McCall, 2005).

According to Janušauskaite (2008), the perception of quality of life as the availability and distribution of material goods or resources has been a key component of quality of life for many years, and the definition of quality of life to satisfy. According to Easterlin (2001), Frey, Stutzer (2002), in economic theory, the concept of quality of life is often associated with the term welfare, which refers to the objective well-being that is most often measured in monetary terms. According to scientific literature, quality of life is determined by the external and internal environment (Hagerty et al., 2001; Veenhoven, 2000, 2005, 2009). 


\section{ENTREPRENEURSHIP AND SUSTAINABILITY ISSUES}

ISSN 2345-0282 (online) http://jssidoi.org/jesi/

2020 Volume 7 Number 4 (June)

http://doi.org/10.9770/jesi.2020.7.4(7)

According to $\mathrm{Wu}$, Zhu (2016) research linking corruption to life satisfaction is limited because life satisfaction has not traditionally been considered a political outcome or a politically relevant event. Only recently have researchers begun to examine the influence of political factors such as regime type, government welfare policy, and political representation on happiness (Bok 2010; Alvarez-Diaz et al. 2010; Di Tella \& MacCulloch, 2005; Haller \& Hadler, 2006; Pacek \& Radcliff, 2008; Radcliff 2001, 2005; Lincényi, Č́rsky, 2020).

Charron et al. (2013) argued that until the mid-1990s, issues of corruption and mismanagement in the social sciences were largely ignored. The main reason behind the rise in the government's quality and good governance agenda has since been the introduction of various types of measures, especially the 1996 one "The Corruption Perceptions Index" (further CPI) published by Transparency International and only later by the World Bank. With the introduction of these and more tools, numerous studies have shown that government institutions that are reasonably devoid of corruption and real practices have a significant positive impact on many outcomes related to the quality of human life. According to Charron, Lapuente (2018), over the last two decades, more and more research has supported the notion that "government quality" - understood as an impartial, efficient and corruptionfree government - is a key factor in explaining socio-economic differences through political communities. Quality of life is a broader concept than economic production and living standards. It includes the full range of factors that influence what we value in living, reaching beyond its material side (Eurostat, 2017).

The classification of quality of life indicators provided by Eurostat is presented in Figure 1.

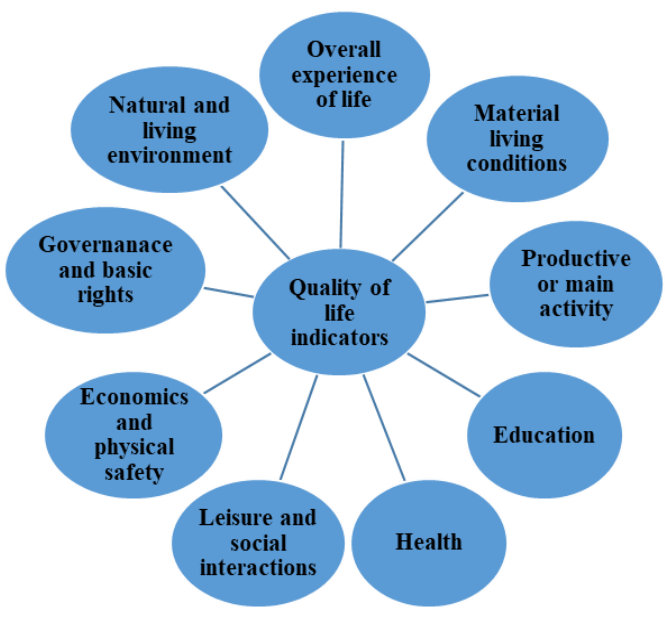

Figure 1. Quality of life indocators. Source: Eurostat

According to Eurostat, 8 of the quality of life indicators provided relate to the ability of people to pursue their own well-being according to their own values and priorities. According to research, middle-income countries with high levels of corruption account for one third of all countries in the world. Infant mortality rates in these countries are three times higher and literacy rates $25 \%$ lower. There is no country in the world where corruption is completely eliminated, but it is argued that emerging countries have a higher risk of corruption.

Researchers who have investigated the relationship between corruption and quality of life give mixed results. According to Cárcaba, et. al. (2017) did not confirm any relationship between transparency and quality of life when investigating municipal financial reporting in Spain. Although no link has been found, the study has shown that involving citizens; views and decision-making in the distribution of finances to municipalities has actually improved the quality of life in Spanish regions. Meanwhile, Wu, Zhu (2016) confirmed by research that the negative impact of corruption on happiness in China. Moreover, it demonstrates that the level of corruption in the 


\section{ENTREPRENEURSHIP AND SUSTAINABILITY ISSUES}

ISSN 2345-0282 (online) http://jssidoi.org/jesi/

2020 Volume 7 Number 4 (June)

http://doi.org/10.9770/jesi.2020.7.4(7)

general environment or the quality of government governance has a particular impact on people's life satisfaction. The research was conducted through surveys with the dependent variable named life satisfaction; and independent variables - experience of corruption, corruption environment. Other research (Enste, Heldman, 2017) found that the main spheres of corruption are size and structure of government, democracy and the political system, determinants and percentage of women in the labor force. The effective functioning / inefficiency of these realms has the greatest impact on people's quality of life. It is concluded that, separately, the quality of life and the phenomenon of corruption are investigated in many ways, i.e. however, there is a lack of correlation between quality of life and corruption. The authors of the article were able to discover only a few studies carried out in Spain, China and the USA.

\section{Research methodology}

Researchers looking at quality of life face the challenge of choosing from a wide range of indicators that influence the quality of life, the most important and significant for quality of life. The article collected the official 15 selected indicators of quality of life in the European Union countries 1990-2018 period statistics. The data in question cover the various economic variables of the various countries which joined the European Union in 1958, 1973, 1981-1986, 1995, 2004 and 2007 respectively. Belgium, Italy, Luxembourg, Netherlands, France, Germany joined the EU in 1958; 1973 - Ireland, Denmark, United Kingdom (withdrew from EU 2020-01-31 but was still a member of the EU at the time of the calculation); 1981-1986 y. - Greece, Spain, Portugal; 1995 - Austria, Sweden and Finland; 2004 - Czech Republic, Estonia, Cyprus, Latvia, Lithuania, Poland, Malta, Slovakia, Slovenia, Hungary; 2007-2013 y. - Bulgaria, Romania, Croatia.

The aim of the empirical study is to develop a model that assesses the extent to which quality of life indicators affect corruption across groups of countries. Quality of life indicators are presented in Table 1.

Table 1. Quality of life indicators

\begin{tabular}{|c|c|c|}
\hline$X$ & Indicator & Description and Source \\
\hline $\mathrm{X} 1$ & Income index & $\begin{array}{l}\text { Income Index of a country based on the Gross National Income at Purchasing Power Parity } \\
\text { per Capital. Income Index is the index of a country's GNI, where GNI (Gross National } \\
\text { Income) is the income claimed by the residents of the country, product taxes etc. } \\
\text { https://www.easycalculation.com/finance/income-index-calculator.php }\end{array}$ \\
\hline $\mathrm{X} 2$ & $\begin{array}{llll}\begin{array}{l}\text { Main } \\
\text { capita }\end{array} & \text { GDP aggregates } & \text { per } \\
\end{array}$ & $\begin{array}{l}\text { Main GDP aggregates per capita: main components from the output, expenditure and } \\
\text { income side, expenditure breakdowns by durability and exports and imports by origin } \\
\text { https://ec.europa.eu/eurostat/cache/metadata/en/nama10_esms.htm }\end{array}$ \\
\hline $\mathrm{X} 3$ & $\begin{array}{l}\text { Employment (as \% of the } \\
\text { population aged } 20 \text { to } 64 \text { ) }\end{array}$ & $\begin{array}{l}\text { The employment rate is calculated by dividing the number of persons aged } 20 \text { to } 64 \text { in } \\
\text { employment by the total population of the same age group. The indicator is based on the } \\
\text { EU Labour Force Survey. The survey covers the entire population living in private } \\
\text { households and excludes those in collective households such as boarding houses, halls of } \\
\text { residence and hospitals. Employed population consists of those persons who during the } \\
\text { reference week did any work for pay or profit for at least one hour, or were not working } \\
\text { but had jobs from which they were temporarily absent. } \\
\text { https://ec.europa.eu/eurostat/web/products-datasets/-/t2020_10 }\end{array}$ \\
\hline $\mathrm{X} 4$ & $\begin{array}{l}\text { Unemployment rates by sex, } \\
\text { age and educational attainment } \\
\text { level }(\%)\end{array}$ & $\begin{array}{l}\text { The unemployment rate is the number of unemployed persons as a percentage of the } \\
\text { labour force (the total number of people employed and unemployed) based on } \\
\text { International Labour Office (ILO) definition. Unemployed persons comprise persons aged } \\
15 \text { to } 74 \text { who fulfil all the three following conditions. } \\
\text { https://ec.europa.eu/eurostat/web/products-datasets/-/tipsun10 }\end{array}$ \\
\hline $\mathrm{X} 5$ & Life expectancy Index & $\begin{array}{l}\text { The life expectancy index measures the relative achievement of a country in terms of life } \\
\text { expectancy at birth. } \\
\text { https://www.eustat.eus/document/datos/pi_metod/idh_idh_i.asp }\end{array}$ \\
\hline X6 & $\begin{array}{l}\text { Life expectancy at birth, total } \\
\text { (years) }\end{array}$ & $\begin{array}{l}\text { Life expectancy at birth indicates the number of years a newborn infant would live if } \\
\text { prevailing patterns of mortality at the time of its birth were to stay the same throughout its } \\
\text { life. } \\
\text { https://datacatalog.worldbank.org/life-expectancy-birth-total-years-0 }\end{array}$ \\
\hline $\mathrm{X} 7$ & Current health expenditure $(\%$ & Level of current health expenditure expressed as a percentage of GDP. Estimates of \\
\hline
\end{tabular}


ENTREPRENEURSHIP AND SUSTAINABILITY ISSUES

ISSN 2345-0282 (online) http://jssidoi.org/jesi/

2020 Volume 7 Number 4 (June)

http://doi.org/10.9770/jesi.2020.7.4(7)

\begin{tabular}{|c|c|c|}
\hline & of GDP) & $\begin{array}{l}\text { current health expenditures include healthcare goods and services consumed during each } \\
\text { year. This indicator does not include capital health expenditures such as buildings, } \\
\text { machinery, IT and stocks of vaccines for emergency or outbreaks. } \\
\text { https://datacatalog.worldbank.org/current-health-expenditure-gdp }\end{array}$ \\
\hline $\mathrm{X} 8$ & Human development index & $\begin{array}{l}\text { The Human Development Index (HDI) is a summary measure of average achievement in } \\
\text { key dimensions of human development: a long and healthy life, being knowledgeable and } \\
\text { have a decent standard of living. The HDI is the geometric mean of normalized indices for } \\
\text { each of the three dimensions. } \\
\text { http://hdr.undp.org/en/content/human-development-index-hdi }\end{array}$ \\
\hline $\mathrm{X} 9$ & Education Index & $\begin{array}{l}\text { Index, which is calculated using Mean Years of Schooling and Expected Years of } \\
\text { Schooling. } \\
\text { http://hdr.undp.org/en/content/education-index }\end{array}$ \\
\hline $\mathrm{X} 10$ & Gender employment gap & $\begin{array}{l}\text { The indicator measures the difference between the employment rates of men and women } \\
\text { aged } 20 \text { to } 64 \text {. The employment rate is calculated by dividing the number of persons aged } \\
20 \text { to } 64 \text { in employment by the total population of the same age group. The indicator is } \\
\text { based on the EU Labour Force Survey. } \\
\text { https://ec.europa.eu/eurostat/web/products-datasets/product?code=sdg_05_30 }\end{array}$ \\
\hline $\mathrm{X} 11$ & $\begin{array}{l}\text { House price index - annual data } \\
(2015=100)\end{array}$ & $\begin{array}{l}\text { The House price index captures price changes of all residential properties purchased by } \\
\text { households (flats, detached houses, terraced houses, etc.), both new and existing, } \\
\text { independently of their final use and their previous owners. Only market prices are } \\
\text { considered, self-build dwellings are therefore excluded. The land component is included. } \\
\text { The data are expressed as annual average index } 2015=100 \text {, as } 3 \text { years } \% \text { change and annual } \\
\text { average rate of change. } \\
\text { https://ec.europa.eu/eurostat/web/products-datasets/product?code=tipsho } 20\end{array}$ \\
\hline $\mathrm{X} 12$ & $\begin{array}{l}\text { Population density (people per } \\
\text { sq. km of land area) }\end{array}$ & $\begin{array}{l}\text { Population density is midyear population divided by land area in square kilometers. } \\
\text { Population is based on the de facto definition of population, which counts all residents } \\
\text { regardless of legal status or citizenship--except for refugees not permanently settled in the } \\
\text { country of asylum, who are generally considered part of the population of their country of } \\
\text { origin. Land area is a country's total area, excluding area under inland water bodies, } \\
\text { national claims to continental shelf, and exclusive economic zones. In most cases the } \\
\text { definition of inland water bodies includes major rivers and lakes. } \\
\text { https://datacatalog.worldbank.org/population-density-people-sq-km-land-area-2 }\end{array}$ \\
\hline $\mathrm{X} 13$ & $\begin{array}{l}\text { Urban population growth } \\
\text { (annual \%) }\end{array}$ & $\begin{array}{l}\text { Urban population refers to people living in urban areas as defined by national statistical } \\
\text { offices. It is calculated using World Bank population estimates and urban ratios from the } \\
\text { United Nations World Urbanization Prospects. } \\
\text { https://datacatalog.worldbank.org/urban-population-growth-annual-5 }\end{array}$ \\
\hline $\mathrm{X} 14$ & $\begin{array}{l}\text { Air pollution effects (Mortality, } \\
\text { per } 1 \text { mln inhabitants) }\end{array}$ & $\begin{array}{l}\text { Fine particulate matter (PM2.5) can be inhaled and cause serious health problems } \\
\text { including both respiratory and cardiovascular disease, having its most severe effects on } \\
\text { children and elderly people. Exposure to PM } 2.5 \text { has been shown to considerably increase } \\
\text { the risk of heart disease and stroke in particular. Cost estimates represent only the cost of } \\
\text { premature mortalities. They are calculated using estimates of the "Value of a Statistical } \\
\text { Life" (VSL) and the number of premature deaths attributable to ambient particulate matter. } \\
\text { https://data.oecd.org/air/air-pollution-effects.htm\#indicator-chart }\end{array}$ \\
\hline $\mathrm{X} 15$ & $\begin{array}{l}\text { Population by educational } \\
\text { attainment level, sex and age } \\
(\%) \text { - main indicators. From } 15- \\
64 \text { years. Less than primary, } \\
\text { primary and lower secondary } \\
\text { education (levels } 0-2)\end{array}$ & $\begin{array}{l}\text { Presents data on the highest level of education successfully completed by the individuals } \\
\text { of a given population. } \\
\text { https://ec.europa.eu/eurostat/cache/metadata/en/edat1_esms.htm }\end{array}$ \\
\hline
\end{tabular}

Source: compiled by the authors

We will construct multivariate regression models by examining the effect of the independent variables included in them on the dependent variable. Python was used for all calculations, modeling and analysis. See Annex 1 for how the data were selected. A study of the effect of independent variables on dependent variable $\mathrm{Y}$ found the importance of variables $\mathrm{X}$ to $\mathrm{Y}: \mathrm{x} 8, \mathrm{x} 2, \mathrm{x} 14, \mathrm{x} 4, \mathrm{x} 6, \mathrm{x} 9, \mathrm{x} 7, \mathrm{x} 12, \mathrm{x} 15$. Univariate linear regression tests were used for this purpose. Multiple regression models will include the following model fit criteria, R Square, Adjusted R2, Akaike's information criterion (AIC), F-statistics, Durbin-Watson statistics and Jarque-Bera test. 


\section{ENTREPRENEURSHIP AND SUSTAINABILITY ISSUES}

ISSN 2345-0282 (online) http://jssidoi.org/jesi/

2020 Volume 7 Number 4 (June)

http://doi.org/10.9770/jesi.2020.7.4(7)

R Square (Coefficient of Determination) explains the percentage of variance explained by covariates in the model. It tells us the proportion of variation in the dependent (response) variable that has been explained by the model. It ranges between 0 and 1. Usually, higher values are desirable but it rests on the data quality and domain. We don't necessarily discard a model based on a low R-Squared value. Its a better practice to look at the AIC and prediction accuracy on validation sample when deciding on the efficacy of a model. AIC is measure of the goodness of fit of an estimated statistical model and can also be used for model selection. Adjusted $R^{2}$ penalizes total value for the number of predictors in the model. It doesn't increase, stays same or decrease unless the newly added variable is truly useful. Therefore, when comparing nested models, it is a good practice to look at Adjusted $\mathrm{R}^{2}$ value over Rsquared. The "F-statistic" and "Prob (F-statistic)" statistics test the overall significance of the regression model. Specifically, they test the null hypothesis that all of the regression coefficients are equal to zero. This tests the full model against a model with no variables and with the estimate of the dependent variable being the mean of the values of the dependent variable. The F-statistic value is the ratio of the mean regression sum of squares divided by the mean error sum of squares. Its value will range from zero to an arbitrarily large number. The low a value of "Prob (F-statistic)" would imply that at least some of the regression parameters are nonzero and that the regression equation does have some validity in fitting the data. The Durbin Watson statistic is a number that tests for autocorrelation in the residuals from a statistical regression analysis. The Durbin-Watson statistic is always between 0 and 4 . A value of 2 means that there is no autocorrelation in the sample. Values from 0 to less than 2 indicate positive autocorrelation and values from more than 2 to 4 indicate negative autocorrelation. The JarqueBera Test, is a test for normality. Normality is one of the assumptions for many statistical tests, like the $t$ test or $F$ test; the Jarque-Bera test is usually run before one of these tests to confirm normality. Prob(JB) $>0.05$ - Normal Distribution, Prob (JB) $<0.0$ - Non-Normal Distribution.

\section{Empirical research results}

Multiple regression models were developed for individual groups of countries (see Table 2).

Table 2. Multiple regression models for corruption in individual groups of EU countries

\begin{tabular}{|c|c|c|c|c|c|c|c|c|c|c|c|c|c|}
\hline Modelis & x2 (GDP) & $\begin{array}{l}\mathrm{x} 4 \\
\text { (Unemplo } \\
\text { yment) }\end{array}$ & $\begin{array}{l}\mathrm{x6} \\
\text { (Life } \\
\text { expectanc } \\
\text { y) }\end{array}$ & $\begin{array}{l}7 \\
\text { (Health } \\
\text { expenditu } \\
\text { re) }\end{array}$ & $\begin{array}{l}\mathrm{x} 8 \\
\text { (HDI) }\end{array}$ & $\begin{array}{l}\mathrm{x} 9 \\
\text { (Education } \\
\text { index) }\end{array}$ & $\begin{array}{l}\mathrm{x} 12 \\
\text { (Populatio } \\
\mathrm{n} \text { desity) }\end{array}$ & $\begin{array}{l}\text { x14 } \\
\text { (Air } \\
\text { polution } \\
\text { effect) }\end{array}$ & $\begin{array}{c}\text { x15 } \\
\text { (Population } \\
\text { by } \\
\text { education) }\end{array}$ & $\mathrm{R}$ & MAE & MSE & RMSE \\
\hline 1958 & 0.001 & 0.619 & -6.250 & & & & -0.031 & -0.074 & -0.486 & 0.969 & 1.91 & 5.91 & 2.43 \\
\hline 1973 & 0.001 & & & & & 99.560 & -0.061 & 0.115 & & 0.911 & 1.95 & 5.70 & 2.39 \\
\hline 1981 & & & & -6.109 & & & & -0.066 & 0.406 & 0.912 & 2.31 & 9.58 & 3.10 \\
\hline 1995 & -0.002 & & & & & & -0.139 & & & 0.876 & 1.92 & 6.65 & 2.58 \\
\hline 2004 & 0.003 & & -1.139 & -1.832 & & & -0.014 & -0.045 & 0.467 & 0.744 & 3.23 & 17.03 & 4.12 \\
\hline 2007 & 0.005 & & 3.587 & & -680.221 & 232.792 & & & & 0.782 & 2.08 & 6.34 & 2.52 \\
\hline
\end{tabular}

Source: compiled by the authors

The models of both R-squared and Adj. R-squared ratios values are close to 1, Prob (F-Statistic) value $<0.05$ indicates that significant variables are included in the model, Prob (JB)>0.05 indicates residual normality, and Durbin-Watson values are close to one, this indicates a positive autocorrelation of residues.

The growth / decline in the corruption perception index of the 1958 group of accession countries is affected by GDP per capita, unemployment, life expectancy, population density, air pollution and educated population (see equation 1):

1958 year $Y=0.0006 X 2+0.6193 X 4-6.2498 X 6-0.0307 X 12-0.0738 X 14-0.4855 X 15+558.2605(1)$ 


\section{ENTREPRENEURSHIP AND SUSTAINABILITY ISSUES}

ISSN 2345-0282 (online) http://jssidoi.org/jesi/

2020 Volume 7 Number 4 (June)

http://doi.org/10.9770/jesi.2020.7.4(7)

During the period under review, GDP per capita increased by 1 million. The CPI tends to increase by 0.001 points and vice versa. This supports the theoretical assumptions that corruption is lower in rich and developed countries. The rise of the CPI shows increasing transparency in the country. The CPI scores are on a 100-point scale where 100 points for a very transparent state and 0 for a very corrupt state. With a $1 \%$ rise in unemployment, the CPI has a tendency to increase by 0.619 points and vice versa. In the scientific literature, corruption in terms of bribery, nepotism, favoritism, commercial bribery, and unlawful favors is positively correlated with unemployment (Dwivendi, 1967). Other studies (Bouzid, 2016) have found that widespread corruption practices force most of the workforce to leave the formal economy, reducing income from taxable labor taxes. The decline in tax revenues weakens the government's capacity to create new jobs, increasing unemployment and the incentives for corrupt officials to take bribes. However, higher unemployment rates may increase corruption, while public officials may be hesitant to bribe in times of high unemployment for fear of losing their jobs. Given the relatively high average wages in this group of countries, bribing is not an attractive option.

With a one-year increase in population life expectancy, the CPI tends to decline by 6.24 points. Lower level of corruption or better control of corruption in a country can lead to longer life expectancy, lower infant mortality rate and lower under-five mortality rate for citizens (Lio, Lee, 2016). Corruption reduction itself is an effective method to promote health, but other researchers have not found significant links between corruption and individual illness. In the 1958 group of countries, life expectancy has been increasing, but CPI has been declining. By one person sq. meter, the CPI tends to drop by 0.031 points. According to Chowdhury (2007), countries with a higher density population are more likely to be categorized under higher corruption indices. This follows as a result of the population's place on increasing strain on governance, thus increasing corruption. With an increase in per capita mortality, the CPI tends to decrease by 0.074 points. Increased human mortality results in worsening health conditions, increased consumption of alcohol or tobacco products, and reduced quality of life, reflecting widespread corruption in countries. With a $1 \%$ increase in the proportion of those with lower than primary or secondary education, CPI tends to fall by 0.486 points, and vice versa. Those with lower levels of education are less conscious of not engaging in corrupt activities.

Studies have shown that citizens with the lowest levels of education are unresponsive to the effects of corruption; for all other citizens, the corrosive effects of corruption on political trust increase with education (Hakhverdian, Mayne, 2012). Life expectancy, unemployment rates and low educational attainment have had the greatest impact on the variation in CPI in Belgium, Italy, Luxembourg, the Netherlands, France and Germany, meaning that attention to quality of life variables included in the multivariate regression model needs to be addressed effectively.

Multivariate regression model for 1973 intervening countries:

1973 year $Y=0.0009 X 2+99.5598 X 9+0.1148 X 14-0.0614 X 12-56.4855$

In this model, in contrast to (1), the new variable, Education index, appears. As the Education index rises 1, the CPI tends to increase by 99.55 .

1981 year $Y=-6.1087 X 7-0.0664 X 14+0.4062 X 15+117.2153$

1995 year $\mathrm{Y}=-0,0016 X 2-0.1388 X 12+126.8781$

2004 year $\mathrm{Y}=0.0029 X 2-1.1392 X 6-1.8323 X 7-0.0140 X 12-0.0447 X 14+0.4667 X 15+134.7901$

2007 year $\mathrm{Y}=0.0051 X 2+3.5871 X 6-680.2210 X 8+232.7916 X 9+87.0062$

In conclusion, the extent of corruption within individual groups of countries was unequivocally influenced by the economic situation of countries, as measured by GDP per capita in this study (except for the countries that joined the EU in 1981). The improving economic situation of groups of countries had a positive effect on the values of the CPI, which indicated an improving situation in the fight against corruption. With the exception of in the 1995 accession countries, the value of GDP showed opposite tendencies in correlation with CPI. Finland, Austria and 


\section{ENTREPRENEURSHIP AND SUSTAINABILITY ISSUES}

ISSN 2345-0282 (online) http://jssidoi.org/jesi/

2020 Volume 7 Number 4 (June)

http://doi.org/10.9770/jesi.2020.7.4(7)

Sweden are among the most transparent countries, although their CPIs have been on a declining trend to 75 points in 2017, Finland from 97 in 2004 to 85 points in 2017, Sweden from 92 in 2004 to 84 points in 2017. The impact of the unemployment rate on the values of the CPI only occurred in the group of countries that joined in 1958. The Life Expectancy Index, which reflects healthy lifestyles and long life expectancy, has a positive effect on CPI values in the group of countries that joined in 2007, signaling that public authorities should focus more on promoting healthy lifestyles and education in Bulgaria, Romania and Croatia. The extent of corruption was further influenced by charges on health care, particularly in 1981 and 2004. for groups of countries.

During the period under review, health and care taxation may have been ineffective in terms of quality ratio, leading to the assumption of increased mistrust in healthcare institutions and increased bribing of health care professionals. The impact of HDI on the value of CPI was only significant for a 2007 group of countries.

\section{Conclusions}

The mathematical statistical calculations revealed that the prevalence of corruption among groups of countries had the greatest impact on the mortality rate, which clearly shows how countries manage their health care system (4 out of 6 countries had a significant impact on corruption), population density, aging issues (4 out of 6 country groups), GDP per capita reflecting the economic situation of the country (5 out of 6 countries), life expectancy serving as an indicator of quality of life ( 3 out of 3 country groups) and primary education number ( 3 groups of 3 countries).

The study revealed that in order to reduce corruption, it is necessary to focus on the following areas reflecting the quality of life: education, health care system and general economic situation in the country. Education in the context of this study was defined by the lack of mentality of those with low levels of education, without realizing the negative consequences of corruption in the long term, the education index and HDI. The health care system was defined by mortality, life expectancy, health care expenditure, population density (which determines population size). It is concluded that by improving at least one of the models' quality of life indicators, the corruption index tends to improve. Further research suggests a more detailed study of the impact of identified quality of life indicators on corruption at national level.

\section{References}

Alvarez-Diaz, A.; Gonzalez, L. \& Radcliff, B. (2010). The politics of happiness: On the political determinants of quality of life in the American states. Journal of Politics, 72, 894-905.

Anderson, T. (2016). A global examination of the relationship between corruption and well-being and happiness. Journal of Politics and Democratization 1(1), 1-22.

Bok, D. (2010). The politics of happiness: What government can learn from the new research on well-being. Princeton University Press. https://doi.org/10.1515/9781400832194

Bouzid, B. N. (2016). Dynamic relationship between corruption and youth unemployment. Empirical evidence from a system GMM approach. World bank group. Policy Research Working Paper 7842. Retrieved from http://documents.worldbank.org/curated/en/916781475156227542/pdf/WPS7842.pdf

Cárcaba, A.; González, E.; Ventura, J.; Arrondo, R. (2017). How does good governance relate to quality of life? Sustainability, 9(631), 116. https://doi.org/10.3390/su9040631 


\section{ENTREPRENEURSHIP AND SUSTAINABILITY ISSUES}

ISSN 2345-0282 (online) http://jssidoi.org/jesi/

2020 Volume 7 Number 4 (June)

http://doi.org/10.9770/jesi.2020.7.4(7)

Charron, N., Lapuente, V., Rothstein, B. (2013). Quality of Government and Corruption from a European Perspective. A Comparative Study of Good Government in EU Regions. Edward Elgar Publishing, p. 239.

Charron, N.; Lapuente, V. (2018). Quality of government in EU regions: spatial and temporal patterns. Working paper series. QOG the Quality og Government Institute.

Chowdhury, N. M. (2007). An Empirical Analysis of Selected Factors Affecting Corruption in the Asia-Pacific Region. Ritsumeikan Journal of Asia Pacific Studies, 27, 1-14.

Di Tella, R. \& MacCulloch, R. J. (2005). Partisan social happiness. Review of Economic Studies, 72,367 - 393.

Dwivendi, O. P. 1967. Bureaucratic Corruption in Developing Countries. Asian Review, 7, 245-253.

Easterlin, R. A. (2001). Income and Happiness: Towards a Unified Theory. The Economic Journal 111, 465-484.

Enste, D.; Heldman, Ch. (2017). Causes and consequences of corruption: An overview of empirical results. IW-Report, No. 2/2017, Institut der deutschen Wirtschaft (IW), Köln. Retriewed from https://www.econstor.eu/bitstream/10419/157204/1/IW-Report-2017-02.pdf

Eurostat (2017). Final report of the expert group on quality of life indicators. Retrieved from: https://ec.europa.eu/eurostat/documents/7870049/7960327/KS-FT-17-004-EN-N.pdf/f29171db-e1a9-4af6-9e96-730e7e11e02f

Eurostat. Retrieved from: https://ec.europa.eu/eurostat/web/gdp-and-beyond/quality-of-life/data

Gruževskis, B.; Orlova, U., L. (2012). Sąvokos „gyvenimo kokybe““ raidos tendencijos (Trends in the development of the concept of quality of life). Socialinis darbas, 11(1), 12-13.

Frey, B. S.; Stutzer, A. (2002). What Can Economists Learn from Happiness Research? Journal of Economic Literature 40(2), $402-435$.

Hagerty, M. R.; Cummins, A. R.; Ferriss, A. L.; Land, K.; Michalos, A. C.; Peterson, M. (2001). Quality of life indexes for national policy: Review and agenda for research. Social Indicators Research, 55, 1-96.

Hakhverdian, A.; Mayne, Q. (2012). Institutional Trust, Education, and Corruption: A Micro-Macro Interactive Approach. Journal of Politics, 74(3), 739-750.

Haller, M. \& Hadler, M. (2006). How social relations and structures can produce happiness and unhappiness: An international comparative analysis. Social Indicators Research, 75, 169-216.

Janušauskaitė, G. (2008). Gyvenimo kokybės tyrimai: problemos ir galimybès (Quality of life research: problems and opportunities). Filosofija. Sociologija, 19(4), 34-44.

Lincényi, M., Čársky, J. 2020. Policy trusts in public policy in the Slovak Republic. Insights into Regional Development, 2(1), 456-468. http://doi.org/10.9770/IRD.2020.2.1(5)

Lio, M. Chi; Lee, M. H. (2016). Corruption costs lives: a cross-country study using an IV approach. The International Journal of Health Planning and Management, 31, 175-190. https://doi.org/10.1002/hpm.2305

McCall, S. (2005). Quality of life. Oxford: Oxford University Press, p. 315.

Pacek, A. C. \& Radcliff, B. (2008). Welfare policy and subjective well-being across nations: An individual-level assessment. Social Indicators Research, 89, $179-191$.

Radcliff, B. (2001). Politics, markets, and life satisfaction: The political economy of human happiness. American Political Science Review, 95(4), $939-952$.

Radcliff, B. (2005). Class organization and subjective well-being: A cross-national analysis. Social Forces, 84(1), 509-526.

Rakauskienè, O. G.; Servetkienè, V. (2011). Lietuvos gyventojų kokybė: 20 metų rinkos (Quality of Lithuanian Population: 20 Years of Market). Monografija, p. 362.

Schuessler, K. F.; Fisher, G. A. (1985). Quality of life research and sociology. Annual Review of Sociology, 11, $129-149$. 


\section{ENTREPRENEURSHIP AND SUSTAINABILITY ISSUES}

ISSN 2345-0282 (online) http://jssidoi.org/jesi/

2020 Volume 7 Number 4 (June)

http://doi.org/10.9770/jesi.2020.7.4(7)

Šumach, $\breve{S}$. 2018. Corruption, Causes and Consequences [E-Reader Version]. Retrieved from https://www.researchgate.net/publication/328081475 Corruption Causes and Consequences

Veenhoven, R. (2000). The Four Qualities of Life: Ordering Concepts and Measures of the Good Life. Journal of Happiness Studies, (1), $1-39$.

Veenhoven, R. (2005). Apparent Quality of Life in Nations. How Long and Happy People Live. Social Indicators Research, (71), 61-68.

Veenhoven, R. (2009). Well-Being in Nations and Well-Being of Nations. Is There a Conflict Between Individual and Society? Social Indicators Research, (91), 5-21.

Wu, Y.; Zhu, J. (2016). When are people unhappy? Corruption experience, environment, and life satisfaction in Mainland China. Journal of Hapiness Studies, 17(3), 1125-1147 https://dx.doi.org/10.1007/s10902-015-9635-7

\section{Acknowledgements}

This research was supported by the project, which has received funding from Phillip Morris Products S.A. [Grant Agreement PRC-9]. The paper is funded by PMI IMPACT, a global grant initiative from Philip Morris International to support projects against illegal trade and related crimes.

Rita REMEIKIENE் is the associate professor of Faculty of Business and Economics, Mykolas Romeris University, LT. She is the international manager of the PMI Impact Project "Interdependence between illegal Turnoever in Tobacco and Corruption, Money Laundering and Organised Crime", the pricipal executive of the national project "Welfare society". Research interests: shadow economy, digital shadow economy, corruption, money laundering, self-employment, entrepreneurship.

ORCID ID: https://orcid.org/0000-0002-3369-485X

Ligita GASPARE்NIENE் is the professor of Faculty of Business and Economics, Mykolas Romeris University, LT. She is the leader of the PMI Impact Project "Interdependence between illegal Turnoever in Tobacco and Corruption, Money Laundering and Organised Crime", the leader of the national project "Welfare society". Research interests: shadow economy, digital shadow economy, corruption, money laundering, investments in gold, monetary policy.

ORCID ID: https://orcid.org/0000-002-5535-6552

Viktoras CHADYŠAS is the associated professor of Faculty of Fundamental Sciences, Vilnius Gediminas Technical University, Vilnius, LT. He is a member of the Society of Lithuanian Mathematicians. Research interests: a comprehensive analysis of data and the application of different statistical methods in various areas of life.

ORCID ID: https://orcid.org/0000-0003-3890-9845

Evaldas RAISTENSKIS is a junior researcher at Vilnius University, Faculty of Law, Department of Criminal Justice, Criminal Law General Science Center. I am currently writing a dissertation work for Criminal Liability for Contraband. Research interests: criminal smuggling, shadow economy, corruption.

ORCID ID: https://orcid.org/0000-0003-3049-2926 


\section{ANNEX 1}

\section{Sampling of data}

The original dataset consists of the number of countries that joined the EU in different years and information on different economic variables over a period of time. It is likely that between the information collected, i.e. the 15 economic indicators will certainly be correlated, interdependent. Therefore, a correlation matrix between all available data and the values of economic indicators is presented first:

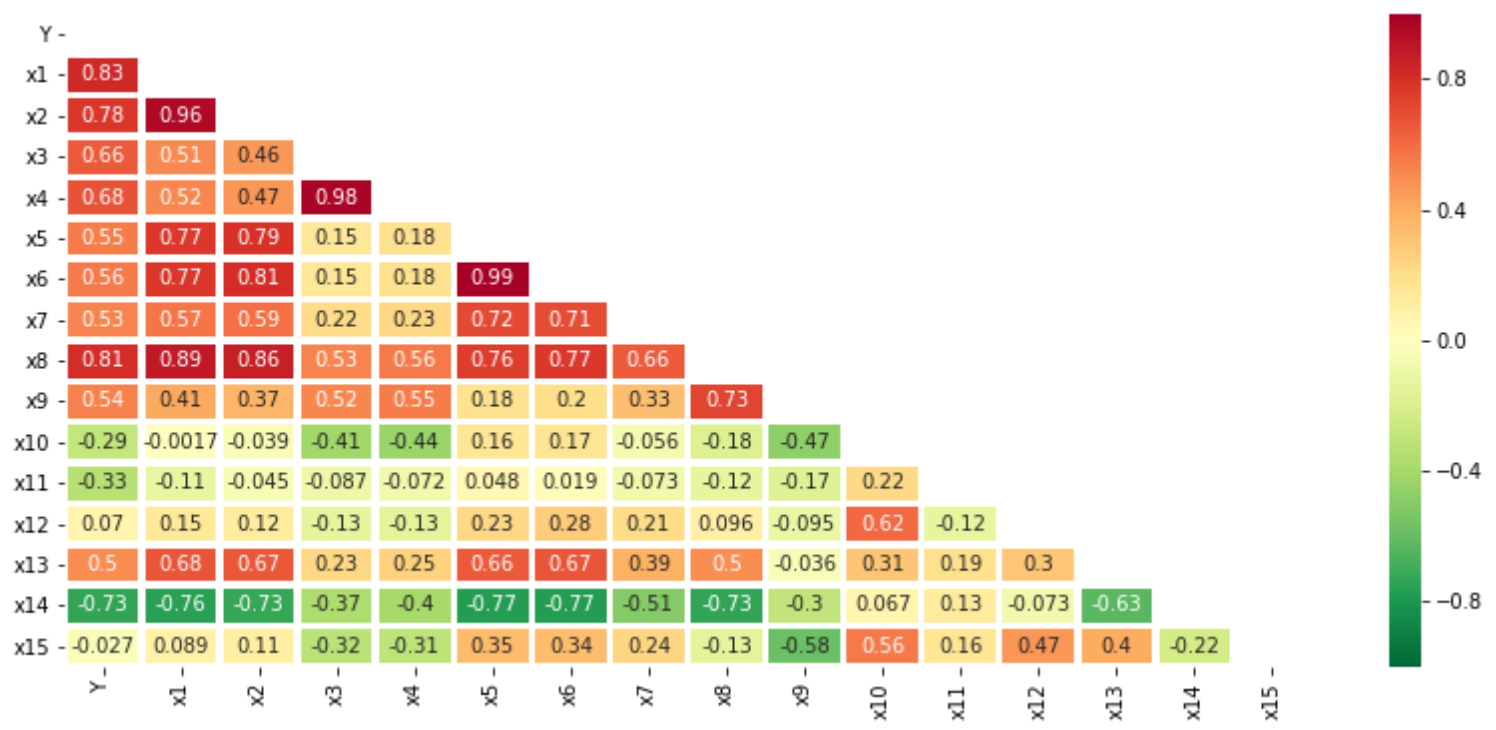

It is easy to see that there is a strong correlation between the whole mass of indicators, i.e. dependent on each other are $\mathrm{x} 1$ (Income index) and x2 (Main GDP aggregates per capita), x3 (Employment (as a percentage of the population aged 20 to 64)) and $x 4$ (Unemployment rates by sex, age and educational attainment level, respectively) \%)), x5 (Life expectancy Index), and x6 (Life expectancy at birth, total (years)). We look at the correlations of these variables differently, by year, for the groups that joined the EU:

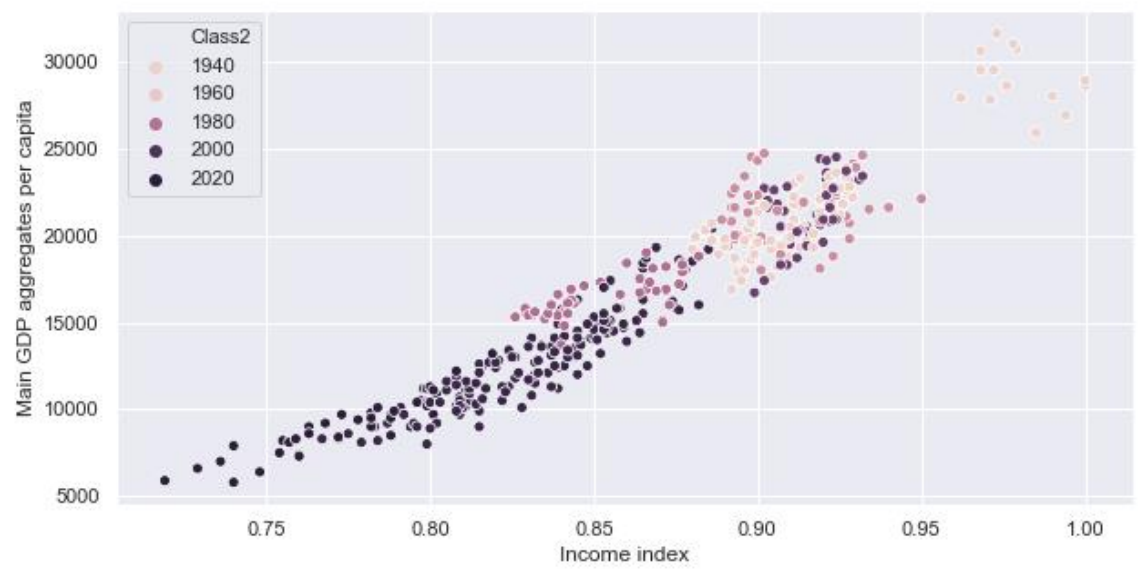


The linear dependence of the presented indicators on all blocks of countries is obvious; The following indicators $\mathrm{x} 3$ and $\mathrm{x} 4$ and $x 5$ and $x 6$ respectively are given below. The differences between the groups of countries are less pronounced, but the correlation is strong for all groups of countries.
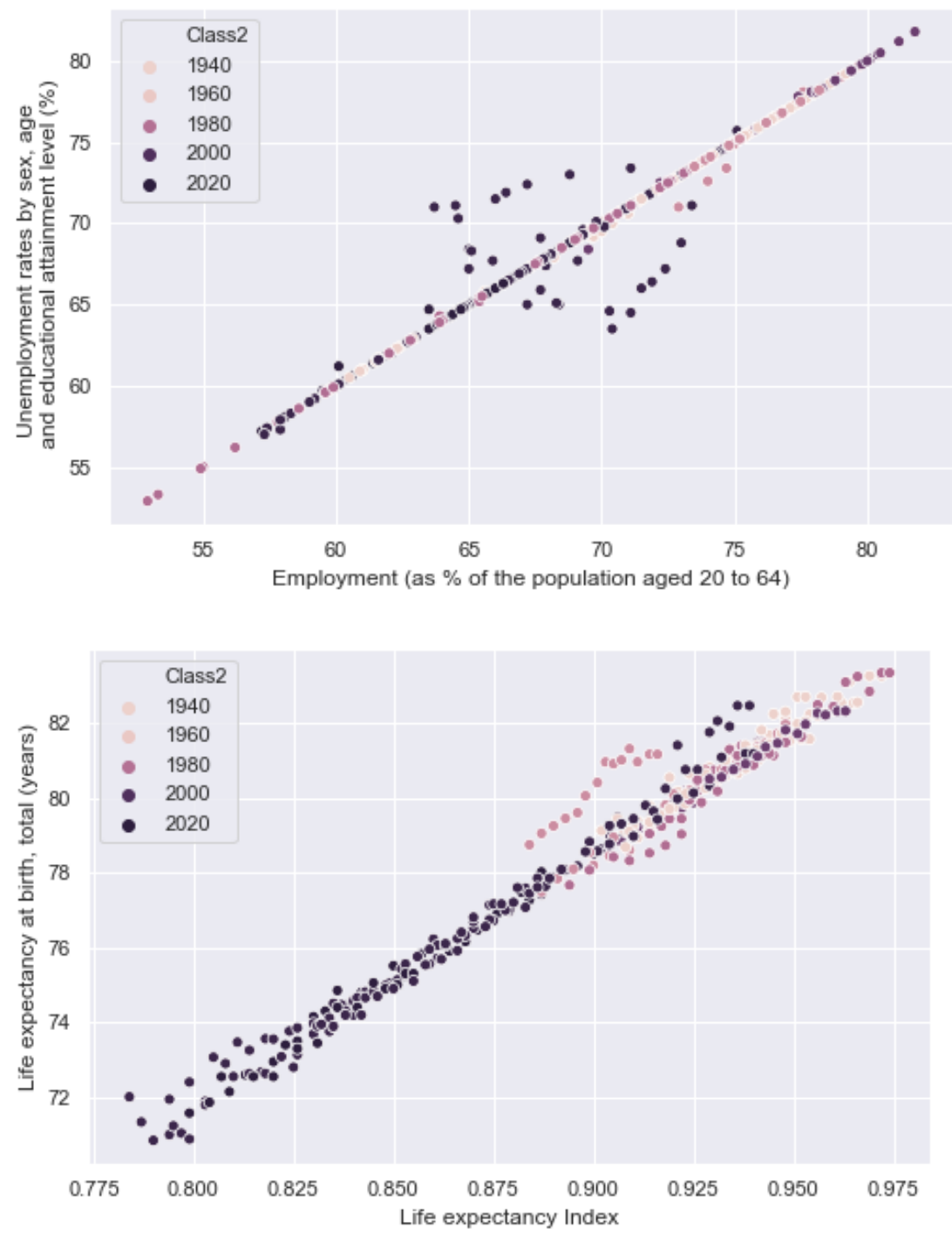

Given the importance of the economic variables mentioned above for dependent variable $\mathrm{Y}$, the attributes $\mathrm{x} 1$, $\mathrm{x} 3$ and $\mathrm{x} 5$, respectively, are further removed from the data analysis. The x10 and x13 attributes have negative values, which are also removed from the original dataset. The x11 indicator has omitted values, and deleting entries with them significantly reduces the data set for the 2007 Accession Countries, eliminating the whole attribute. Missed values also have the x14 attribute, but we believe it is important for analysis, so the entries are removed, not the attribute itself. Distribution of data records, number of meanings by groups of countries joining the EU. 